\title{
PEMBELAJARAN BERBASIS INQUIRI MELALUI PENGEMBANGAN BLOG PEMBELAJARAN FISIKA DALAM MATA KULIAH MULTIMEDIA
}

\author{
Rudy Kustijono \\ Jurusan Fisika Universitas Negeri Surabaya \\ rudyunesa@gmail.com
}

\begin{abstract}
Abstrak
Telah dilakukan penelitian pengembangan pembelajaran berbasis inquiri melalui pengembangan blog pembelajaran fisika dalam mata kuliah multimedia. Tujuan penelitian adalah untuk mendeskripsikan pembelajaran berbasis inquiri tersebut, mengetahui dampak pengembangan blok pembelajaran fisika terhadap proses inquiri mahasiswa, dan mengetahui apakah pembelajaran tersebut dapat dikategorikan PAIKEM yaitu pembelajaran yang aktif, inovatif, kreatif, efektif, dan menyenangkan. Jenis penelitian yang dilakukan adalah Penelitian dan Pengembangan atau Research and Development $(R \& D)$, dengan langkah penelitian studi pendahuluan, pengembangan produk dan ujicoba produk. Pokok bahasan penelitian adalah materi yang berhubungan dengan fisika dan aplikasinya, sedangkan ujicoba terbatas diterapkan pada mahasiswa Jurusan Fisika Unesa yang berjumlah 50 orang yang sedang memprogram mata kuliah multimedia pada semester gasal tahun akademik 2012-2013. Hasil penelitian menunjukkan bahwa pengembangan blog pembelajaran fisika dapat merefleksikan proses tahapan inquiri mahasiswa dengan baik (planning $\geq 80 \%$, retrieving $\geq 85 \%$, processing $\geq 75 \%$, creating $\geq 70 \%$, sharing $\geq 95 \%$, dan evaluating $\geq 80 \%$ ). Di samping itu pembelajaran berbasis inquiri melalui pengembangan blog pembelajaran fisika dalam mata kuliah multimedia tersebut dapat dikategorikan sebagai PAIKEM karena semua kriteria yang ada mendapatkan penilaian yang baik dari mahasiswa (aktifitas 96\%, inovasi 90\%, kreatifitas $94 \%$, efektifitas $86 \%$, dan menyenangkan $86 \%$ ).
\end{abstract}

Kata kunci: TIK, Inquiri, Blog, PAIKEM. 


\section{Pendahulian}

Ketika di sekolah, tugas-tugas yang berhubungan dengan penerapan di dunia nyata yang melibatkan emosi dan pikiran akan menjadi memori positif yang sulit terlupakan di kemudian hari. Hal tersebut seringkali adalah projek penyelidikan yang melibatkan kerja bersama dengan orang lain. Inquiri menciptakan pengalaman belajar, membangkitkan keingintahuan, dan kegembiraan pada siswa melalui projek penyelidikan. Pembelajaran berbasis inquiri adalah proses dimana siswa terlibat dalam pembelajaran mereka, merumuskan pertanyaan, menyelidiki secara luas dan kemudian membangun pemahaman, makna, dan pengetahuan baru. Pengetahuan baru tersebut bagi para siswa dapat digunakan untuk menjawab pertanyaan, mengembangkan penyelesaian atau mendukung kinerja. Penelitian menunjukkan bahwa pembelajaran berbasis inquiri dapat membantu siswa menjadi lebih kreatif, lebih positif, dan lebih mandiri. Penelitian lain menunjukkan bahwa pembelajaran berbasis inquiri dapat meningkatkan prestasi siswa (Alberta Learning, 2004). ${ }^{[1]}$ Brickman dkk (2009) ${ }^{[2]}$ menemukan bahwa ada peningkatan yang lebih besar pada pemahaman sains dan keterampilan penyelidikan siswa ketika menggunakan panduan laboratorium berbasis inquiri. Mereka juga menemukan bahwa siswa-siswa yang terlibat dalam pembelajaran berbasis inquiri memperoleh kepercayaan diri ketika mengembangkan kemampuan ilmiah

Selain meningkatkan motivasi siswa, salah satu alasan utama untuk menggunakan pembelajaran berbasis inquiri adalah karena dapat menyediakan sarana agar siswa terlibat aktif dalam proses pembelajaran. Tren pembelajaran saat ini adalah menjauhi pengajaran yang berpusat pada guru ke pendekatan yang lebih berpusat pada siswa, Pembelajaran berbasis inquiri memberi kesempatan pada kita untuk membantu siswa mempelajari konsep dengan memberi kesempatan mereka mengeksplorasi pertanyaan, mengembangkan dan menguji hipotesis. Dengan demikian dapat memberikan siswa lebih banyak kesempatan untuk merefleksikan pembelajaran mereka sendiri, mendapatkan pemahaman yang lebih dalam tentang konsep-konsep dengan cara yang terintegrasi, dan menjadi pemikir kritis yang lebih baik. Abd-El-Khalick dkk $(2004)^{[3]}$ mendapatkan di banyak negara bahwa posisi pengajaran sains itu memiliki ke khasan. Guru sains menghindari hafalan dan hanya fakta-fakta kecil dari ilmu pengetahuan. Guru sains mengembangkan pengajaran dengan metode ilmiah, berpikir kritis, sikap ilmiah, pendekatan pemecahan masalah, metode penemuan (discovery), dan metode penyelidikan (inquiry).

Satu model pengajaran yang dapat digunakan untuk mendukung kerja guru dan siswa adalah model inquiri seperti gambar 1 berikut (Donham, 2001):

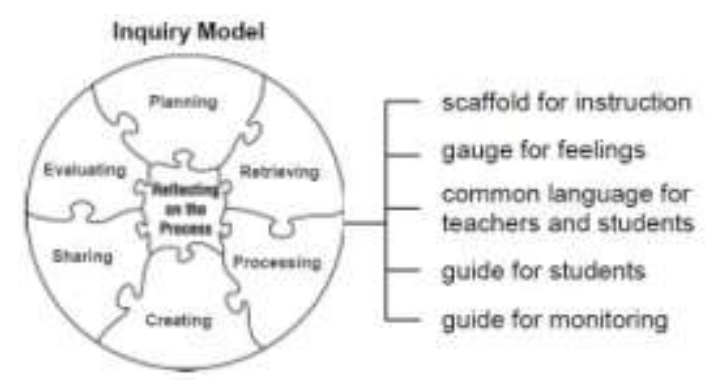

Gambar 1. Model Inquiri

Model inquiri sebagai scaffolding pengajaran yaitu menyediakan konten dan struktur untuk pengajaran yang menguraikan keterampilan dan strategi yang perlu diajarkan secara eksplisit dalam setiap tahapan proses. Di garis depan, perencanaan pembelajaran berbasis inquiri menyiapkan masalah dan menciptakan bahan pembelajaran.

Model inquiri sebagai ukuran perasaan yaitu pengalaman belajar yang menuntut dan membawa berbagai perasaan seperti antusiasme, frustrasi, ketakutan, dan kegembiraan. Perasaan ini dialami dengan pola tertentu dalam berbagai tahapan dari proses inquiri. Mengacu pada kegiatan pembelajaran berbasis inquiri tersebut, guru dapat mengantisipasi dan mengenali 
siswa ketika mengalami perasaan yang kuat dan mampu untuk merancang sistem dukungan dan kegiatan reflektif yang membantu siswa bergerak melalui proses.

Model inquiri sebagai bahasa bersama guru dan siswa yaitu bahasa yang membantu siswa untuk menginternalisasi model dan pembicaraan tentang proses keterlibatan dalam pembelajaran. Hal ini meningkatkan komunikasi yang efektif antara semua yang terlibat dalam inquiri di sekolah karena guru dan siswa menyampaikan kata-kata untuk membicarakan bagian-bagian dari proses. Implementasi model di kelas dan di perpustakaan mendorong siswa mengenali setiap tahap sebagai bagian dari keseluruhan proses.

Model inquiri sebagai panduan bagi siswa yaitu panduan dalam menggunakan pendekatan analitis yang mencakup semua tahapan dalam proses penyelidikan. Tanpa belajar proses inquiri, siswa sering mengembangkan pandangan yang sangat terbatas dan sempit tentang penyelidikan. Mereka mungkin berpikir bahwa inquiri adalah menemukan jawaban pertanyaan orang lain yaitu kepuasan gurunya, bukan memahami inquiri sebagai proses mempertanyakan tentang sesuatu, menghasilkan pertanyaan-pertanyaan mereka dan menggunakan informasi untuk memenuhi kepentingan mereka serta untuk mengembangkan pengetahuan mereka sendiri.

Model inquiri sebagai panduan untuk memantau yaitu guru menggunakannya untuk menilai seberapa efektif siswa terlibat dalam proses penyelidikan, seberapa dalam mereka memahami hal itu, dan seberapa efektif proses telah diurutkan di kelas. Siswa dapat memperoleh pengalaman dan praktek yang mereka butuhkan dalam pembelajaran berbasis inquiri tanpa guru berlebih beban.

Refleksi proses merupakan bagian integral dari semua tahapan dalam model inquiri yang meliputi: planning (perencanaan), retrieving (pengambilan), processing (pengolahan), creating (penciptaan), sharing (berbagi), dan evaluating (penilaian) yang mencakup ranah afektif dan kognitif yang terkait dengan metakognisi. Refleksi proses dalam model inquiri adalah seperti gambar 2 (Alberta Learning, 2004) ${ }^{[1]}$ :

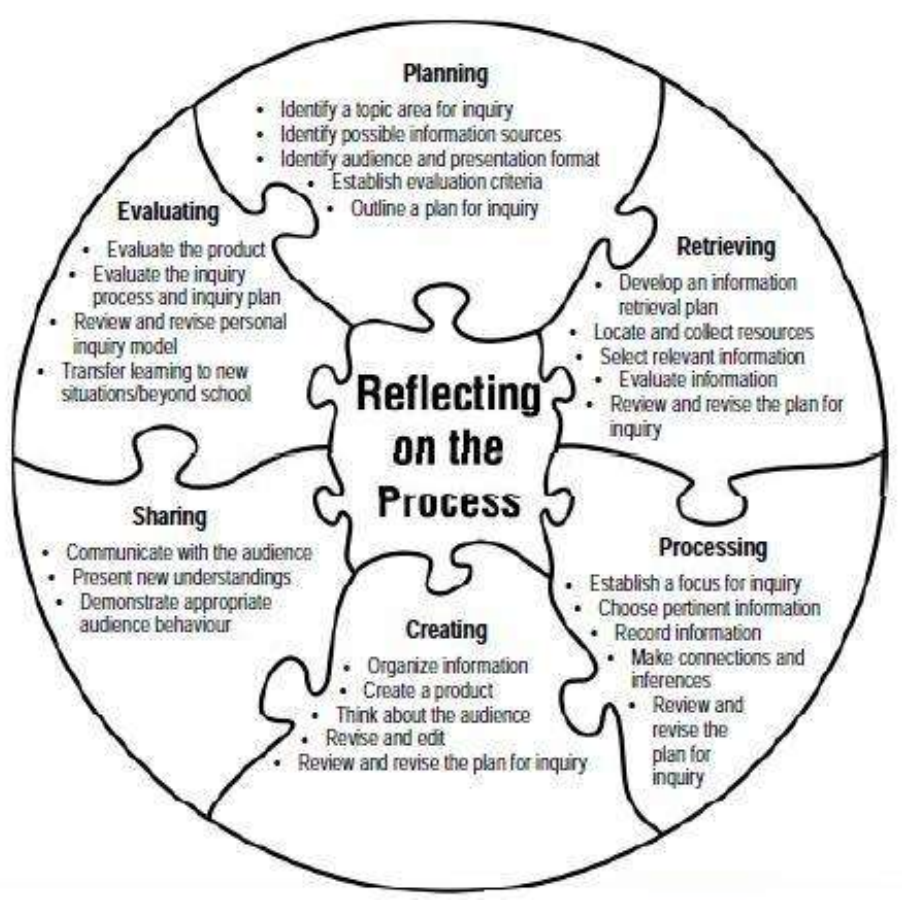

Gambar 2. Refleksi proses inquiri 
Penjelasan masing-masing tahapan dalam model inquiri tersebut adalah sebagai berikut:

a. Tahap Perencanaan \{Planning)

Siswa harus memahami bahwa tujuan yang mendasari pembelajaran berbasis projek inquiri adalah untuk mengembangkan keterampilan "belajar untuk belajar" mereka. Pembelajaran berbasis inquiri dimulai dengan kepentingan siswa tentang rasa ingin tahu suatu topik yaitu teka-teki yang harus dipecahkan. Tahap ini adalah tahapan proses inquiri yang paling penting dari keseluruhan proses karena untuk memberikan rasa optimisme siswa tentang tugas-tugas ke depan.

b. Tahap pengambilan (Retrieving)

Para siswa berikutnya berpikir tentang informasi yang mereka miliki dan informasi yang mereka inginkan. Siswa mungkin perlu meluangkan banyak waktu mengeksplorasi dan berpikir tentang informasi yang telah ditemukan sebelum memfokus pada penyelidikan. Tahapan pertama harus menyenangkan bagi siswa, karena mereka secara aktif mencari informasi yang terkait dengan topik. Mereka mungkin dapat meningkatkan jumlah sumber yang ditemukan, tetapi kadang-kadang siswa berhenti mencari, karena mereka mungkin tidak tahu bagaimana menangani data yang tidak relevan atau tidak dapat menemukan data khusus yang diperlukan. Karena banyak yang mereka ingin ketahui, mereka sering menjadi frustasi pada saat proses ini. Guru perlu membantu siswa melewati perasaan frustrasi dengan mengajarkan bahwa perasaan ini adalah dialami oleh semua orang yang melakukan penyelidikan, juga mengajarkan keterampilan dan strategi memilih informasi yang relevan, serta menyesuaikan dan memodifikasi penyelidikan.

c. Tahap pengolahan (Processing)

Tahap ini dimulai ketika siswa telah menemukan fokus penyelidikan. Menuju ke fokus bisa sangat sulit bagi siswa, karena melibatkan lebih dari sekedar penyempitan topik. Hal ini melibatkan pertanyaan otentik, perspektif pribadi dan/atau pernyataan yang menarik. Siswa biasanya mengalami rasa lega dan kegembiraan ketika mereka telah membentuk fokus penyelidikan. Meskipun demikian, memilih informasi terkait dari sumber-sumber adalah tugas yang sulit, mungkin ada informasi yang terlalu sedikit atau terlalu banyak, atau informasi yang mungkin terlalu dangkal atau terlalu mendalam bagi siswa. Seringkali informasi yang ditemukan membingungkan dan bertentangan, sehingga siswa dapat merasa kewalahan.

d. Tahap penciptaan (Creating)

Tugas berikutnya dalam proses adalah mengorganisir informasi, menempatkan informasi ke dalam kata-kata sendiri dan menciptakan format presentasi. Siswa akan merasa lebih percaya diri pada tahap ini dan ingin mencakup semua pelajaran baru dan produk mereka, sehingga banyak sekali informasi.

e. Tahap berbagi (Sharing)

Jika siswa telah diberikan kesempatan cukup dalam mendukung seluruh proses penyelidikan, mereka akan bangga dengan produk mereka dan ingin berbagi, terlepas sebagai penyaji atau pendengar. Mereka mungkin merasa sedikit gugup menyajikan sesuatu yang mereka miliki tersebut, dan mereka mungkin merasa cemas bahwa orang lain mungkin tidak mengerti atau menghargai usaha mereka. Meskipun demikian, mereka merasa telah melakukan tugas ini dengan baik.

f. Tahap penilaian (Evaluating)

Akhirnya, ketika sebuah proyek penelitian selesai, siswa merasa lega dan bahagia. Mereka sangat antusias tentang pemahaman dan keterampilan baru mereka, dan mereka ingin merefleksikan penilaian proses dan produk penyelidikan mereka. Dalam rangka memahami proses penyelidikan, mereka perlu bertanya dan memahami kriteria penilaian, untuk mengidentifikasi langkah-langkah dalam proses penyelidikan mereka, dan untuk berbagi perasaan. Siswa harus mampu mengartikulasikan pentingnya bekerja 
semacam ini untuk mengembangkan keterampilan "belajar untuk belajar", dan mereka harus dapat melihat hubungan antara kerja penyelidikan yang dilakukan di sekolah dan pekerjaan atau kegiatan yang dilakukan di luar sekolah. Mereka juga harus dapat merefleksikan bagaimana pengalaman mereka dalam model inquiri dan apa yang telah mereka pelajari telah mempengaruhi pribadi mereka.

Ketika kita merancang program untuk pembelajaran berbasis inquiri, kita perlu melihat siswa dengan dua dimensi yang berbeda (Kustijono, 2012) ${ }^{[5]}$. Pertama, kita perlu mempertimbangkan tingkat akademis siswa. Artinya, apa yang sudah mereka ketahui tentang konsep dan prosedur dalam pembelajara, misalnya mereka telah mengambil pelajaran prasyarat, mereka memiliki pengalaman dunia nyata yang akan membantu mereka memahami isi pembelajaran, dan pengetahuan lain yang mungkin mereka miliki. Kedua, kita perlu mempertimbangkan jumlah pengalaman mereka dalam melakukan penyelidikan atau melakukan proses penelitian. Hal ini penting dianalisis sehingga kita tidak melebih-lebihkan pengalaman mereka. Ketika kita mulai merencanakan pembelajaran, tingkat pengalaman mereka akan menentukan jumlah struktur dan pemodelan yang perlu dikembangkan (Lane, 2007) ${ }^{[6]}$.

Hasil Penelitian Akinoglu (2008) ${ }^{[7]}$ tentang penilaian proses penerapan tugas berbasis inquiri dalam pendidikan sains menunjukkan bahwa metode yang paling banyak digunakan dalam sains dan teknologi adalah eksperimen. Siswa dalam mengerjakan tugas terinspirasi memilih sendiri topik tugas mereka, kemudian menelusuri publikasi ilmiah, mencermati peristiwa terkini, menggali materi sains dan teknologi, dan informasi lainnya. Sumber utama yang digunakan oleh siswa untuk mengumpulkan informasi adalah internet. Sebagian besar siswa menganggap bahwa manfaat yang diperoleh melalui karya tugas adalah peningkatan minat tentang sains dan teknologi. Selain itu, mereka berpikir bahwa keterampilan kreatif dapat dikembangkan, tingkat kepercayaan diri, rasa ingin tahu tentang sains, dan karya ilmiah meningkat. Walaupun siswa mengalami beberapa masalah (mencari topik projek, menemukan sumber, rentang waktu), mereka yakin bahwa mengerjakan tugas berbasis inquiri membawa banyak keuntungan.

Untuk mempersiapkan sumber daya manusia abad 21, pembelajaran harus mengacu pada konsep belajar yang dicanangkan oleh UNESCO dalam wujud empat pilar pendidikan ("the four pillars of education") yaitu: belajar untuk mengetahui ("learning to know"), belajar melakukan sesuatu ("learning to do"), belajar menjadi diri sendiri ("learning to be"), dan belajar hidup bersama ("learning to life together") sebagai dasar untuk berpartisipasi dan bekerjasama dengan orang lain dalam keseluruhan aktivitas kehidupan manusia.

Model pembelajaran yang diperlukan adalah yang memungkinkan terbudayakannya kecakapan berpikir ilmiah, terkembangkannya "sense of inquiry" dan kemampuan berpikir kreatif siswa (De Vito, 1989 $)^{[8]}$. Model pembelajaran yang dibutuhkan adalah yang mampu menghasilkan kemampuan untuk belajar (Joice \& Weil, 1996) $)^{[9]}$, bukan saja diperoleh sejumlah pengetahuan, keterampilan, dan sikap saja, tetapi yang lebih penting adalah bagaimana pengetahuan, keterampilan, dan sikap itu diperoleh siswa. Untuk keperluan tersebut, model pembelajaran berbasis keterampilan proses sains diharapkan dapat menjadi alternatif. Model pembelajaran berbasis keterampilan proses sains adalah model pembelajaran yang mengintegrasikan keterampilan proses sains ke dalam sistem penyajian materi secara terpadu (Beyer, 1991 ${ }^{[10]}$. Model ini menekankan pada proses pencarian pengetahuan dari pada transfer pengetahuan, siswa dipandang sebagai subjek belajar yang perlu dilibatkan secara aktif dalam proses 
pembelajaran, guru hanyalah seorang fasilitator yang membimbing dan mengkoordinasikan kegiatan belajar siswa. Dalam model ini siswa diajak untuk melakukan proses pencarian pengetahuan berkenaan dengan materi pelajaran melalui berbagai aktivitas proses sains sebagaimana dilakukan oleh para ilmuwan dalam melakukan penyelidikan ilmiah (Nur , 1998) ${ }^{[11]}$, dengan demikian siswa diarahkan untuk menemukan sendiri berbagai fakta, membangun konsep, dan nilai-nilai baru yang diperlukan untuk kehidupannya. Fokus proses pembelajaran diarahkan pada pengembangan keterampilan siswa dalam memproses pengetahuan, menemukan dan mengembangkan sendiri fakta, konsep, dan nilai-nilai yang diperlukan. Siswa diberi kesempatan untuk langsung terlibat dalam aktivitas dan pengalaman ilmiah seperti apa yang dilakuka/dialami oleh ilmuwan. Dengan demikian siswa dididik dan dilatih untuk terampil dalam memperoleh dan mengolah informasi melalui aktivitas berpikir dengan mengikuti prosedur (metode) ilmiah, seperti terampil melakukan pengamatan, pengukuran, pengklasifikasian, penarikan kesimpulan, dan pengkomunikasian hasil temuan. Model pembelajaran ini merupakan strategi "guided discovery" yang membantu siswa belajar untuk belajar ("learn to learn"), membantu siswa memperoleh pengetahuan dengan cara menemukannya sendiri (Carin \& Sund, 1989 $)^{[12]}$. Di dalam model ini juga tercakup penemuan makna ("meanings"), organisasi, dan struktur dari ide atau gagasan, sehingga secara bertahap siswa belajar bagaimana mengorganisasikan dan melakukan penelitian. Pembelajaran hendaknya menekankan pada kemampuan siswa dalam menemukan sendiri ("discover") pengetahuan yang didasarkan atas pengalaman belajar, hukum-hukum, prinsip-prinsip dan generalisasi, sehingga lebih memberikan kesempatan bagi berkembangnya keterampilan berpikir tingkat tinggi (Houston, 1988) ${ }^{[13]}$. Dengan demikian siswa lebih diberdayakan sebagai subjek belajar yang harus berperan aktif dalam mencari informasi dari berbagai sumber belajar, dan guru lebih berperan sebagai organisator dan fasilitator pembelajaran.

Perkembangan TIK (Teknologi Informasi dan Komunikasi) yang sangat pesat membawa perubahan besar pada segala bidang termasuk bidang pendidikan. Hartono (2004) ${ }^{[14]}$ mengemukakan bahwa pemanfaatan TIK untuk meningkatkan mutu pendidikan dapat dilakukan dengan berbagai cara, salah satunya adalah dalam pembelajaran. Proses pembelajaran dengan memanfaatkan TIK diyakini akan mempermudah pemahaman materi pelajaran. Perkembangan TIK yang sangat pesat membawa konsekuensi tentang pentingnya penyediaan sumber daya manusia (SDM) yang mampu memanfaatkan teknologi tersebut. Pendidikan masa depan dituntut harus mampu melibatkan teknologi secara terpadu dalam pembelajaran. Untuk memenuhi kebutuhan tersebut, Jurusan Fisika Unesa mencantumkan mata kuliah "Multimedia" yaitu mata kuliah yang melatih mahasiswa agar mampu mengapresiasi hasil karya berbasis multimedia pembelajaran, mampu menerapkan multimedia dalam media pembelajaran presentasi, mampu mengembangkan media video pembelajaran, mampu mengembangkan website dan weblog, dan mampu mengembangkan media pembelajaran animasi. Bagaimanapun yang bersangkutan harus mengusai materi fisika agar tidak terjadi kesalahan konsep pada media pembelajaran yang dibuatnya. Untuk itu, pembelajaran dalam mata kuliah multimedia tersebut haruslah berbasis inquiri.

Salah satu yang dikembangkan mahasiswa adalah blog pembelajaran fisika. Embi (2011) ${ }^{[15]}$ menyatakan pada umumnya, weblog atau blog merupakan catatan pribadi, ruang kolaboratif, saluran berita terkini dan koleksi catatan pandangan pribadi. Blog bisa berisii apa saja yang 
diinginkan. Terdapat banyak bentuk dan jenis blog, dan tidak ada aturan baku mengenainya. Singkatnya, blog adalah satu laman web untuk membuat catatan secara terus-menerus. Hal yang baru ditampilkan pada bagian paling atas agar pengunjung dapat membaca catatan terkini. Kemudian mereka dapat memberikan komentar terhadap apa yang ditampilkan tersebut, membuat tautan padanya atau mengirim email. Dalam bidang pendidikan, blog digunakan untuk memenuhi berbagai bentuk keperluan komunikasi yang membantu penerapan pembelajaran elektronik (Susana \& Sergio 2007) ${ }^{[16]}$.

Menurut Susana dan Sergio (2007) ${ }^{[16]}$, blog mempunyai beberapa kelebihan:

a. Mudah dikembangkan dan dikelola dibandingkan dengan teknologi yang lain.

b. Lebih mudah dalam memaparkan semua jenis sumber informasi (teks, gambar, video, dsb.) ke internet menggunakan blog jika dibandingkan dengan menggunakan web konvensional.

c. Dapat diterbitan segera dengan hanya satu klik, mudah untuk diatur dan dikelola dibandingkan dengan laman web biasa yang memerlukan banyak waktu, usaha, dan pengetahuan reka bentuk laman web (HTML, CSS, JavaScript).

d. Dapat dikemas dengan mudah dari mana saja tanpa memerlukan sambungan FTP, perisian pengarangan web dan sebagainya.

e. Dapat melibatkan pengunjung yang lebih ramai tanpa kehilangan mutu informasi dan membenarkan berbagai tahap rincian informasi, dan dapat menyeimbangkan antara jangkauan dengan kekayaan informasi.

f. Informasi yang ditampilkan di blog dapat diperoleh selama 24 jam pada waktu dan di mana saja

g. Tidak ada perisaian blog tertentu yang diperlukan dalam membuatnya. Sebagian penulis blog (blogger) menggunakan HTML ringkas untuk membuat blog mereka. Walau bagaimanapun, kebanyakan membuat dan mengelola blog tanpa memerlukan pengetahuan HTML. Guru tidak perlu meminta log pembelajaran siswa secara terusmenerus.

h. Berbagai teknologi lain dapat digunakan bersama blog.

Sedangkan manfaat penggunaan blog yang dinyatakan oleh Anamaria (2010) ${ }^{[17]}$.

a. Blog membolehkan pelajar yang mempunyai kemahiran web menggunakan sumber informasi kegemaran mereka (melalui internet) secara sah dan sesuai serta mengaplikasikan kemahiran mereka dalam program tersebut.

b. Dapat meningkatkan motivasi siswa agar aktif dalam proses pembelajaran karena menulis blog harus memikat dan menarik.

c. Dapat mengembangkankemampuan berkomunikasi siswa yang kurang mahir internet melalui pembelajaran teman sebaya.

d. Dapat memberi siswa informasi terkini mengenai bahan pembelajaran mereka.

e. Dapat mengembangkan pemikiran kritis (dan juga cara-cara yang sesuai untuk mengutarakan pemikiran tersebut dalam bentuk tulisan) melalui penggunaan ruang komentar dan bentuk balikan yang lain.

f. Dapat menjadi portal kreatit dan inisiatif sendiri, karena gagasan yang bagus bukan saja diberi ganjaran melalui markah yang tinggi, bahkan mendapat respon secara langsung dari pengunjung blog.

g. Dapat membuat program yang direncanakan lebih mudah dilihat di internet dan memberikan gambaran positif yang jelas, dan dapat menghasilkan komitmen yang tinggi dari siswa terhadap program tersebut dan perasaan bangga terhadap hasil kerja mereka.

h. Dapat menjadikan pembelajaran lebih adil dan setara, bukan secara hierarki, dan guru bertindak sebagai pendamping, bukan sebagai satusatunya sumber informasi dan tafsiran. 
Menurut Susana dan Sergio $(2007)^{[16]}$, blog dapat digunakan oleh guru dan siswa sebagai berikut:

Blog Guru adalah blog yang ditulis oleh guru yang kebanyakan digunakan sebagai satu saluran komunikasi tambahan untuk berbagi informasi dengan siswa. Blog guru biasanya mengandung informasi berkaitan kandungan pelajaran, pengelolaan pelajaran, komentar kepada siswa tentang kemajuan pembelajaran mereka, dan sebagainya.

Blog Siswa adalah blog yang dibuat oleh siswa yang pada dasarnya adalah blog pembelajaran atau blog projek. Blog pembelajaran (Lowe 2006) ${ }^{[18]}$ merupakan suatu catatan pembelajaran, yang dibuat serentak dengan pengalaman pembelajaran, dan memberikan laporan tentang kandungan serta proses pembelajaran (termasuk waktu yang diambil, sumbersumber yang digunakan dan sebagainya). Blog projek yang biasanya ditulis oleh sekumpulan siswa untuk mencatatkan perkembangan dan perolehan projek.

Memperhatikan karakteristik pembelajaran yang berbasis inquiri dan karakteristik blog pembelajaran seperti diuraikan di atas, penulis memandang, blog dapat digunakan untuk mendukung pembelajaran berbasis inquiri di sekolah atau di kampus yang hasilnya diyakini cukup efektif. Oleh karena itu diperlukan penelitian pengembangan pembelajaran berbasis inquiri melalui pengembangan blog pembelajaran fisika. Pertanyaan penelitian yang dapat dikemukakan adalah:

a. Bagaimanakah pembelajaran berbasis inquiri melalui pengembangan blog pembelajaran fisika dalam mata kuliah multimedia?

b. Bagaimanakah dampak pengembangan blok pembelajaran fisika terhadap proses inquiri mahasiswa?

Hasil pembelajaran berbasis inquiri tersebut diharapkan dapat menjadi satu alternatif pembelajaran efektif yang menggunakan teknologi informasi dan komunikasi (TIK). Di samping itu juga dapat digunakan sebagai pendorong agar pengembangan blog di kalangan mahasiswa dapat diberdayakan untuk penggunaan yang lebih bermanfaat. Bagi proses pembelajaran dalam mata kuliah "multimedia" sendiri, diharapkan dapat menjadi PAIKEM yaitu pembelajaran yang aktif, inovatif, kreatif, efektif, dan menyenangkan.

\section{Metode Penelitian}

Penelitian yang dilakukan termasuk dalam jenis Penelitian dan Pengembangan atau lebih dikenal dengan Research and Development $(R \& D)$ yaitu suatu proses atau langkah untuk mengembangkan suatu produk baru atau menyempurnakan produk yang telah ada, yang dapat dipertanggungjawabkan. Produk tersebut tidak selalu berbentuk benda atau perangkat keras (hardware), seperti buku, modul, alat bantu pembelajaran di kelas atau laboratorium, tetapi bisa juga perangkat lunak (software), seperti program komputer pengolah data, ataupun modelmodel pendidikan, pembelajaran, pelatihan, bimbingan, evaluasi, manajemen (Sukmadinata, 2012) ${ }^{[18]}$. Langkah penelitian yang dilakukan secara garis besar adalah:

a. Studi pendahuluan yang meliputi studi literatur, studi lapangan, dan penyusunan draf awal produk.

b. Pengembangan produk yang terdiri dari melakukan ujicoba terbatas dan melakukan ujicoba luas,

c. Ujicoba produk melalui eksperimen dan sosialisasi produk.

Karena keterbatasan penulis, penelitian yang dilakukan hanya sampai pada langkah 2 dengan ujicoba terbatas dan belum melakukan ujicoba produk melalui eksperimen dan sosialisasi produk. Langkah-langkah penelitian tersebut dapat divisualisasikan seperti gambar 3 (Sukmadinata, 2012) ${ }^{[18]}$. 


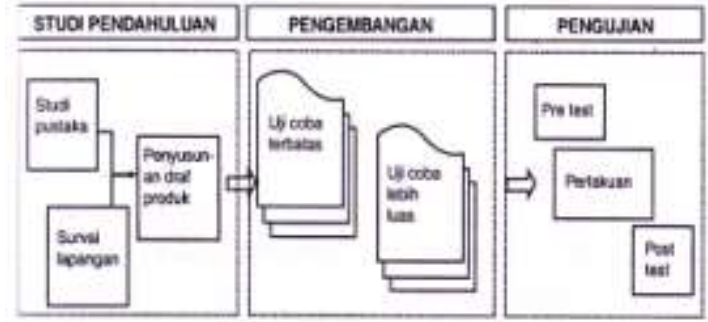

Gambar 3. Langkah-langkah dalam R\&D

Pemilihan pokok bahasan dalam penelitian ini bebas asalkan yang berhubungan dengan fisika dan aplikasinya, sedangkan ujicoba terbatas diterapkan pada mahasiswa Jurusan Fisika Unesa yang berjumlah 50 orang yang sedang memprogram mata kuliah multimedia. Pemilihan jurusan semata-mata didasarkan pada kemudahan akses yang dimiliki penulis sehingga sangat mendukung keberhasilan penelitian. Langkah-langkah penelitian yang telah dilakukan terinci sbb: a. Studi pendahuluan yang meliputi: pengkajian tentang media pembelajaran, pengkajian tentang karakteristik mahasiswa fisika, pengkajian tentang hasil penelitian terdahulu yang relevan, pengkajian karakteristik blog atau weblog, dan pengkajian karakteristik fisika, serta membuat rencana pembelajarannya,

b. Selanjutnya (masih bagian studi pendahuluan) mengembangkan pembelajaran berbasis inquiri melalui pengembangan blog atau weblog pembelajaran fisika. Langkah pembelajaran berbasis inquiri melalui pengembangan blog pembelajaran fisika adalah sbb:

- Membuat blog guru dan memposting berbagai artikel yang berhubungan dengan fisika dan aplikasinya. Selanjutnya memerintahkan semua mahasiswa agar mengunjungi blog tersebut dan memberikan apresiasi terhadap artikel-artikel yang diposting tersebut dengan memberikan komentar.

- Untuk merefleksikan proses tahapan inquiri yang meliputi: perencanaan (planning), pengambilan (retrieving), pengolahan (processing), penciptaan (creating), berbagi (sharing), dan penilaian (evaluating), masingmasing mahasiswa diminta membuat blog siswa yaitu blog pembelajaran yang berhubungan dengan fenomena atau aplikasi fisika Artikel-artikel yang diposting diharapkan diberi ilustrasi gambar atau video untuk memperjelas uraian dalam artikel.

c. Untuk melengkapi refleksi proses tahapan inquiri, mahasiswa juga diminta memberikan komentarnya terhadap artikel-artikel yang diposting mahasiswa lain, dan memberikan balikan terhadap komentar yang diberikan mahasiswa lain terhadap artikel yang dipostingnya.

d. Pengembangan produk yang meliputi: mempersiapkan lembar telaah untuk tim dosen, angket respon mahasiswa tentang dampak pengembangan blog pembelajaran terhadap refleksi proses tahapan inquiri, dan melakukan ujicoba terbatas. Refleksi proses tahapan inquiri mahasiswa yang tercermin dari penjelasan dan komentar masing-masing mahasiswa tersebut selanjutnya ditelaah oleh tim dosen untuk dinilai apakah refleksi proses tahapan inquiri mahasiswa dalam kategori baik atau kurang. Di samping itu, juga dibagikan angket kepada mahasiswa untuk mengetahui dampak pengembangan blog pembelajaran fisika terhadap refleksi proses tahapan inquiri. Di samping itu, juga disebarkan angket kepada mahasiswa untuk mengetahui apakah pembelajaran berbasis inquiri melalui pengembangan blog pembelajaran fisika dapat dikategorokan sebagai PAIKEM yaitu pembelajaran yang aktif, inovatif, kreatif, efektif, dan menyenangkan.

Analisis data yang digunakan dalam penelitian ini adalah statistik deskriptif Data yang bersifat kuantitatif diolah dengan statistik yang sesuai, sedangkan data yang bersifat kualitatif diolah secara deskriptif. 


\section{Hasil dan pembahasan}

Langkah awal pembelajaran adalah membuat blog guru. Ada dua blog yang dibuat dalam pembelajaran ini yaitu yang diberi nama "Rudy Unesa" dan "Fisika dan Pembelajaran", kemudian memposting berbagai artikel yang berhubungan dengan fisika dan aplikasinya. Selanjutnya memerintahkan masing-masing mahasiswa mengunjungi blog tersebut dan memberikan apresiasi dengan memberikan komentar terhadap artikel-artikel yang diposting. Blog "Rudy Unesa" dan "Fisika dan Pembelajaran" tersebut mempunyai tampilan sepert gambar 4 .

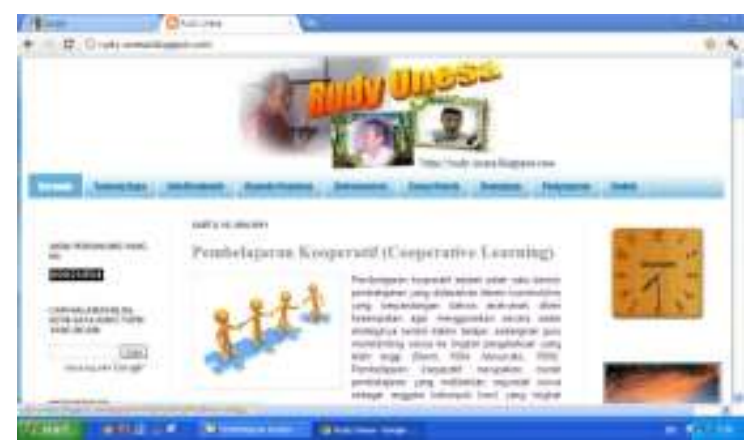

Gambar 4a. "Rudy Unesa"

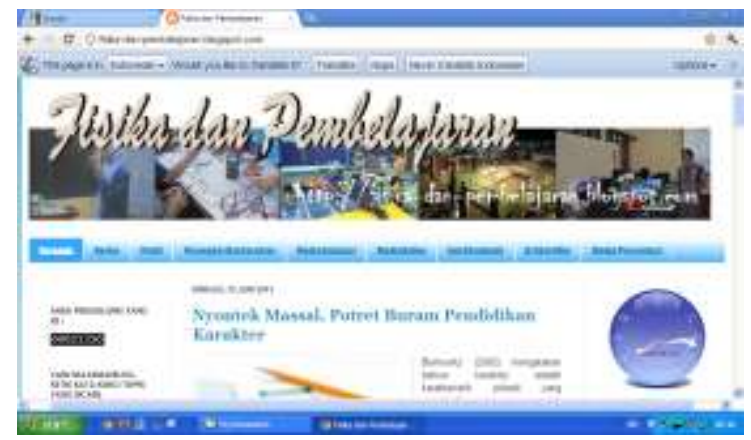

Gambar 4b. "Fisika dan Pembelajaran"

Untuk merefleksikan proses tahapan inquiri yang meliputi: perencanaan (planning), pengambilan (retrieving), pengolahan (processing), penciptaan (creating), berbagi (sharing), dan penilaian (evaluating), masing-masing mahasiswa diminta membuat blog siswa yaitu blog pembelajaran yang berhubungan dengan fenomena atau aplikasi fisika Artikelartikel yang diposting diharapkan diberi ilustrasi gambar atau video untuk memperjelas uraian dalam artikel. Salah satu contoh tampilan blog siswa seperti gambar 5.

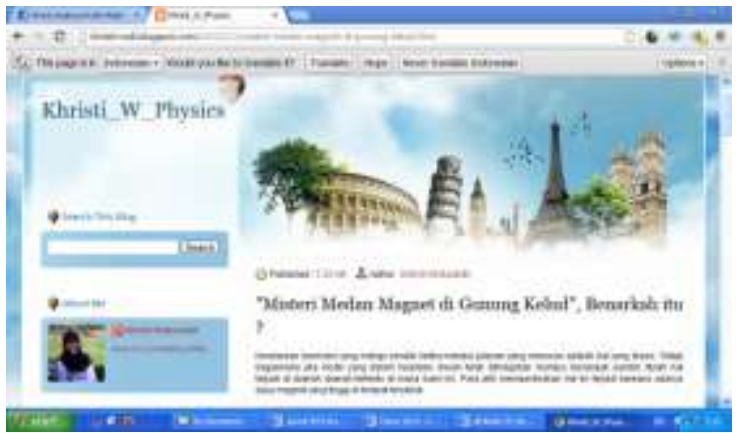

Gambar 5. Satu contoh blog siswa

Untuk melengkapi refleksi proses tahapan inquiri, mahasiswa juga diminta memberikan komentarnya terhadap artikelartikel yang diposting mahasiswa lain, dan memberikan balikan terhadap komentar yang diberikan mahasiswa lain terhadap artikel yang dipostingnya. Salah satu contoh komentar mahasiswa terhadap artikel yang diposting mahasiswa lain seperti gambar 6 .

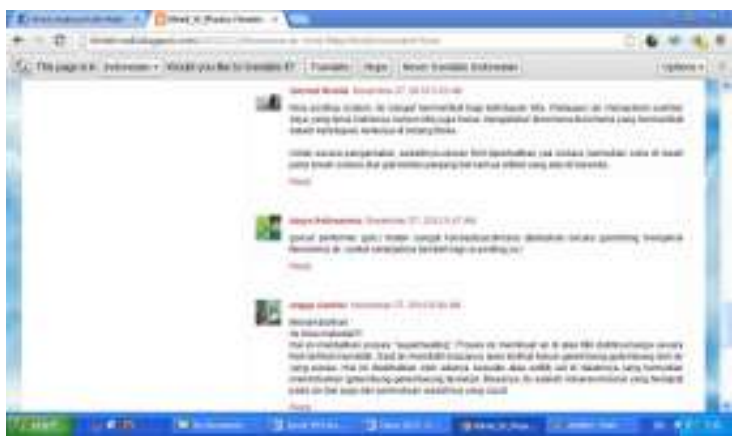

Gambar 6. Contoh komentar mahasiswa

Refleksi proses tahapan inquiri mahasiswa yang tercermin dari penjelasan dan komentar masing-masing mahasiswa tersebut selanjutnya ditelaah oleh tim dosen untuk dinilai apakah refleksi proses tahapan inquiri mahasiswa dalam kategori baik atau kurang. Di samping itu mahasiswa diberi angket untuk menilai dampak pengembangan blog pembelajaran terhadap refleksi proses tahapan inquiri. Untuk memandu agar mahasiswa tidak mengalami kesulitas dalam menilai, dan tidak melalukan kesalahan akibat salah interpretasi tentang refleksi proses tahapan inquiri yang dimaksud, pada angket tersebut diberikan deskripsi tentang 
refleksi proses tahapan inquiri. Hasil penilaian dari dosen maupun mahasiswa selanjutnya direkapitulasi dan dihitung persentasinya berdasarkan kriteria penilaian baik dan kurang. Hasil penilaian dosen dan penilaian mahasiswa tentang dampak pengembangan blog pembelajaran terhadap refleksi proses tahapan inquiri seperti tabel 1. Sedangkan hasil penilaian mahasiswa terhadap pembelajaran berbasis inquiri melalui pengembangan blog pembelajaran fisika terkait PAIKEM seperti tabel 2.

Tabel 1. Dampak pengembangan blog pembelajaran fisika terhadap refleksi proses tahapan inquiri

\begin{tabular}{|c|c|c|c|c|c|}
\hline \multirow{2}{*}{ No. } & \multirow{2}{*}{ Keterampilan } & \multicolumn{2}{|c|}{ Penilaian Dosen } & \multicolumn{2}{|c|}{ Penilaian Mahasiswa } \\
\hline & & Baik (\%) & Kurang (\%) & Baik (\%) & Kurang (\%) \\
\hline 1 & $\begin{array}{l}\text { Perencanaan } \\
\text { (Planning) }\end{array}$ & 80 & 20 & 96 & 4 \\
\hline 2 & $\begin{array}{l}\text { Pengambilan } \\
\text { (Retrieving) }\end{array}$ & 85 & 15 & 98 & 2 \\
\hline 3 & $\begin{array}{l}\text { Pengolahan } \\
\text { (Processing) }\end{array}$ & 75 & 25 & 82 & 18 \\
\hline 4 & $\begin{array}{l}\text { Penciptaan } \\
\text { (Creating) }\end{array}$ & 70 & 30 & 80 & 20 \\
\hline 5 & $\begin{array}{l}\text { Berbagi } \\
\text { (Sharing) }\end{array}$ & 95 & 5 & 100 & 0 \\
\hline 6 & $\begin{array}{l}\text { Penilaian } \\
\text { (Evaluating) }\end{array}$ & 80 & 20 & 86 & 14 \\
\hline
\end{tabular}

Tabel 2. Penilaian mahasiswa terhadap pembelajaran terkait PAIKEM

\begin{tabular}{|c|l|c|c|}
\hline \multirow{2}{*}{ No. } & \multirow{2}{*}{ Keterampilan } & \multicolumn{2}{|c|}{ Penilaian Mahasiswa } \\
\cline { 3 - 4 } & & Baik (\%) & Kurang (\%) \\
\hline 1 & Aktifitas & 96 & 4 \\
\hline 2 & Inovasi & 90 & 10 \\
\hline 3 & Kreatifitas & 94 & 6 \\
\hline 4 & Efektifitas & 86 & 14 \\
\hline 5 & Menyenangkan & 86 & 14 \\
\hline
\end{tabular}

Berdasarkan data diatas tampak bahwa penilaian dosen maupun mahasiswa sendiri mengarah pada penilaian yang baik (planning $\geq 80 \%$, retrieving $\geq 85 \%$, processing $\geq 75 \%$, creating $\geq 70 \%$, sharing $\geq 95 \%$, dan evaluating $\geq 80 \%$ ). Hal tersebut menunjukkan bahwa pengembangan blog pembelajaran fisika dapat merefleksikan proses tahapan inquiri mahasiswa. Di samping itu pembelajaran berbasis inquiri melalui pengembangan blog pembelajaran fisika dalam mata kuliah "multimedia" tersebut dapat dikategorikan sebagai PAIKEM karena semua kriteria yang ada mendapatkan penilaian yang baik dari mahasiswa (aktifitas 96\%, inovasi 90\%, kreatifitas $94 \%$, efektifitas $86 \%$, dan menyenangkan $86 \%$ ). Rasionalisasi hasil tersebut dapat dijelaskan sbb: a. Perencanaan (Planning): Ketika mahasiswa akan membuat blog, dan memposting artikel, mahasiswa harus memahami bahwa tujuan yang mendasari pembelajaran berbasis projek adalah untuk mengembangkan keterampilan "belajar untuk belajar". Oleh karena itu, pembelajaran dimulai dengan kepentingan akan rasa ingin tahu suatu topik dalam fisika dan aplikasinya yaitu masalah yang harus dipecahkannya.

b. Pengambilan (Retrieving): Ketika mahasiswa akan mengembangkan blog pembelajaran fisika dan memposting artikel-artikel fisika dan aplikasinya, mahasiswa perlu berpikir tentang informasi yang mereka miliki dan informasi yang mereka inginkan. Mahasiswa mungkin perlu meluangkan 
banyak waktu mengeksplorasi dan berpikir tentang informasi yang telah ditemukan sebelum memfokus pada penyelidikan.

c. Pengolahan (Processing): Ketika mahasiswa akan memposting artikel-artikel fisika dan aplikasinya, atau akan mengomentari artikel-artikel mahasiswa lain, mahasiswa harus menemukan fokus penyelidikan. Menuju ke fokus bisa sangat sulit bagi mahasiswa, karena melibatkan lebih dari sekedar penyempitan topik. Hal ini melibatkan pertanyaan otentik, perspektif pribadi dan/atau pernyataan yang menarik.

d. Penciptaan (Creating): Ketika mahasiswa memposting artikel-artikel fisika dan aplikasinya serta mengomentari artikel-artikel yang diposting mahasiswa lain, mahasiswa harus mengorganisir informasi, menempatkan informasi ke dalam kata-kata sendiri dan menciptakan format penulisan. Mahasiswa akan merasa lebih percaya diri pada tahap ini dan ingin mencakup semua pelajaran baru dan produk mereka, sehingga banyak sekali informasi yang diperolehnya.

e. Berbagi (Sharing): Ketika saling memberikan komentar terhadap artikelartikel yang dipostingnya, mahasiswa diberikan kesempatan cukup dalam mendukung seluruh proses penyelidikan, mereka akan bangga dengan produk mereka dan ingin berbagi, terlepas sebagai penyaji atau komentator. Mereka mungkin merasa gugup dalam menyajikan sesuatu yang mereka miliki tersebut, dan mereka mungkin merasa cemas bahwa orang lain mungkin tidak mengerti atau menghargai usaha mereka. Meskipun demikian, mereka merasa telah melakukan tugas ini dengan baik.

f. Penilaian (Evaluating): Ketika mahasiswa sudah memposting artikel-artikel fisika dan aplikasinya, mahasiswa akan merasa lega dan senang. Mereka sangat antusias tentang pemahaman dan keterampilan baru mereka, dan mereka ingin merefleksikan penilaian proses dan produk penyelidikannya, melalui saling memberikan komentar terhadap artikel-artikel yang telah dipostingnya. Dalam rangka memahami hasil penyelidikan, mereka perlu bertanya dan memahami kriteria penilaian, untuk mengidentifikasi langkah-langkah penyelidikannya, dan untuk berbagi perasaan.

\section{Kesimpulan}

Pembelajaran berbasis inquiri melalui pengembangan blog pembelajaran fisika dilaksanakan dengan membuat blog guru dan blog siswa, selanjutnya memposting artikel-artikel tentang fisika dan aplikasinya. Untuk melengkapi refleksi proses tahapan inquiri, mahasiswa diberikan kesempatan untuk saling memberikan komentar terhadap artikel-artikel yang dipostingnya (mengkritisi, memperluas dan memperkaya penjelasan)

Berdasarkan penilaian dosen maupun mahasiswa menunjukkan bahwa pengembangan blog pembelajaran fisika dapat merefleksikan proses tahapan inquiri mahasiswa dengan baik (planning $\geq 80 \%$, retrieving $\geq 85 \%$, processing $\geq 75 \%$, creating $\geq 70 \%$, sharing $\geq 95 \%$, dan evaluating $\geq 80 \%$ ). Di samping itu pembelajaran berbasis inquiri melalui pengembangan blog pembelajaran fisika dalam mata kuliah "multimedia" tersebut dapat dikategorikan sebagai PAIKEM karena semua kriteria yang ada mendapatkan penilaian yang baik dari mahasiswa (aktifitas 96\%, inovasi 90\%, kreatifitas $94 \%$, efektifitas $86 \%$, dan menyenangkan $86 \%$ ).

Berdasarkan hasil penelitian tersebut, maka pembelajaran berbasis inquiri melalui pengembangan blog pembelajaran fisika dapat menjadi satu alternatif pembelajaran efektif yang menggunakan teknologi informasi dan komunikasi (TIK), karena berdampak signifikan terhadap refleksi proses tahapan inquiri mahasiswa, dan dapat dikategorikan PAIKEM. 


\section{Daftar Pustaka}

[1] Alberta Learning, 2004. Learning and Teaching Resources Branch. Focus on inquiry: a tea-cher's guide to implementing inquiry-based learning. Alberta, Canada

[2] Brickman P., Gormally C., Armstrong N., Hallar B., 2009, Effects of Inquiry-based Learning on Students' Science Literacy Skills and Confidence. International Journal for the Scholarship of Teaching and Learning Vol. 3, No. 2 (July 2009) ISSN 1931-4744 @ Georgia Southern University

[3] Abd-El-Khalick F., Boujaoude S., Duschi R., Lederman N.G., Hofstein A., Mamlok-Naama R., Niaz M., Treagust D., Tuan H., 2004, Inquiry in Science Education: International Perspectives. Wiley Periodicals, Inc.

[4] Donham, J. (2001). The importance of a model. In J. Donham, K. Bishop, C. C. Kuhlthau, \& D. Oberg (Eds.), Inquiry-based learning: Lessons from Library Power. Worthington, $\mathrm{OH}$ : Linworth.

[5] Kustijono R., 2012, Keterampilan Proses Sains dalam Praktikum Fisika Dasar di Jurusan Fisika FMIPA Unesa, Prosiding Seminar Nasional Sains Program Pascasarjana Unesa 2012, ISBN: 978-979-028-534-7.

[6] Lane, Jill L., 2007, Inquiry Based Learning. Schreyer Institute for Teaching Excellence. Penn State University Park;

[7] Akinoglu O., 2008, Assessment of The Inquiry-Based Project Implementation Processs in Science Education Upon Student's Point of Views. International Journal of Instruction. January 2008 Vol.1, No.1. ISSN: 1694-609X.

[8] De Vito, Alfred. 1989. Creative Wellsprings for Science Teaching. West Lafayette, Indiana: Creative Venture.
[9] Joice, Bruce and Marsha Weil. 1996. Model of Teaching. Boston: Allyn and Bacon.

[10] Beyer, Barry K. 1991. Teaching Thinking Skill: A Handbook for Elementary School Teachers. New York, USA: Allyn \& Bacon

[11] Nur, Mohamad (Editor). 1998. Proses Belajar Mengajar dengan Metode Pendekatan Keterampilan Proses. Surabaya: SIC.

[12] Carin, Arthur A and Robert B. Sund, 1989. Teaching Science Through Discovery. Columbus, Ohio: Merril Publishing Company

[13] Houston, W. Robert., et all. 1988. Touch the Future Teach. St. Paul, MN: West Publishing Company

[14] Hartono, B., (2004), Pemanfaatan TIK dalam Pembelajaran. Tersedia pada http://www. bebeasli.com.

[15] Embi M.A., 2011. Aplikasi Web 2.0 Dalam Pengajaran \& Pembelajaran, Pusat Pembangunan Akademik Universiti Kebangsaan Malaysia. Cetakan Pertama 2011 Universiti Kebangsaan Malaysia

[16] Susana de Juana-Espinosa \& Sergio Lujan-Mora. 2007. The use of weblogs in higher education: Benefits and barriers.

[17] Anamaria Dutceac Segesten. 2010. Blogs in higher education - some ideas abouttheir benefits and downsides.http://uvenus.org/2010/06 /07/blogs-in-highereducation $\%$ E2\% $80 \% 93$-some-ideas-abouttheir-benefits-and-downsides/html

[18] Lowe, A.J. 2006. Blog use in teaching - Dragster activity. Internet: http://www.webducate.net/ dragster2/examples/bloguse

[19] Sukmadinata, 2012, Metode Penelitian Pendidikan, Remaja Rosdakarya, Bandung. 